\author{
Total Quality Management in Library and Information Sectors \\ by \\ Golnessa Galyani Moghaddam \\ Department of Library and Information Science, Shahed University, Tehran, \\ Iran, and \\ Mostafa Moballeghi \\ Department of Industrial Management, Islamic Azad University (IAU), \\ Tehran, Iran
}

\begin{abstract}
The concept of quality management originated in Japan and later moved into the USA and other countries industry. Since then, the theory of quality management has been growing fast. TQM was initially applied as a management philosophy in the manufacturing sector. Following its enormous success, this philosophy is increasingly being applied in the service sector, including libraries. The purpose of this paper is to present an overview of total quality management (TQM) in the library and information sectors. Focusing on TQM implementation in the library and information sectors, the experiences of libraries adopting this method are also reviewed. At last the authors explain the barriers to TQM implementation in libraries.
\end{abstract}

\title{
Introduction
}

The concept of quality management originated in Japan and later moved into the USA and the UK, initially in the manufacturing sector. Since then, the theory of quality management has been growing fast. It has become a management philosophy in its own right and has taken shape in a series of international standards in the ISO 9000 series. The philosophy is increasingly being applied in the service sector, including libraries. This paper focuses on total quality management (TQM) in the library sector. Library and information managers (LIMs) are these days deluged with advice as to how to acquire and organize learning resources and satisfy the complex and everincreasing information needs of their users. However, to achieve their goal, the question of a resource-constrained regime has to be kept in mind without sacrificing the interests of users. The services offered, accordingly, have to be internally efficient and externally effective. It is in this context that the question of "total quality" becomes relevant in the management of library and information services.

\section{TQM concepts}

TQM is the art of managing the whole to achieve excellence. The golden rule is a simple but effective way to explain it. TQM is defined as both a philosophy and a set of guiding principles that represent the foundations of a continuously improving organization. It is the application of qualitative methods and human resources to improve all the processes within an organization and exceed customer needs now and in the future. TQM integrates fundamental management techniques, existing improvements, and technical tools under a disciplined approach (Talukder and Ghosh, 2004).

In the other words, TQM is focused on the understanding that organizations are systems with processes that have the purpose of serving customers. TQM calls for the integration of all organizational activities to achieve the goal of serving customers. It seeks to impose standards, achieve efficiencies, define roles of individuals within 
processes and the organization as a whole, reduce errors and defects by applying statistical process control, and to employ teams to plan and execute processes more efficiently. It requires leaders who are willing to create a culture in which people define their roles in terms of quality outputs to customers.

TQM addresses the issues of customer satisfaction and guidance on implementing the marketing concept. The 1980s brought about a business process of continuous improvement to satisfy customers' needs (Churchill and Paul, 1994). Through an external focus on customer satisfaction and an internal focus on operational excellence, TQM has promised superior performance. TQM also offers managers a host of supporting tools and organizational prescription (Churchill and Paul, 1994). The "total quality" concept is a general philosophy of management which goes well beyond the marketing customer-perceived view of quality by including all key requirements that contribute not only to customer-perceived quality, but also customer satisfaction (Buzzell and Gale, 1987; Garvin, 1988; Zeithaml et al., 1990; Price and Chen, 1993).

The early 1990s brought recognition of this total quality concept by various management scholars. Numerous studies have been conducted and a range of books has been devoted entirely to total quality, focusing exclusively on product and service quality management.

The concept of continuous improvement is a critical success factor of any organization and should be used as the foundation stone upon which every successful TQM initiative should be built. This view is shared by Handy (1994), who stated: "the world keeps changing. It is one of the paradoxes of success that the things and ways that get you where you are, are seldom the things that keep you there”.

The main components of TQM are supported by a number of techniques and activities. If TQM is to be successful in an organization it must be actively supported by senior management. Schein (1991) identified one of the common causes of failure of TQM programs as being a lack of top management commitment. If employees are confident that senior management strongly supports a TQM initiative they are more likely to become involved in that organization's TQM efforts. Successful employee empowerment and involvement are essential components of any TQM program.

Torrington and Hall (1995) stated that "difficulties experienced in adopting TQM have mainly focused on people issues".

\section{TQM principles}

TQM is the application of a number of activities with perfect synergy. The various important elements of TQM are:

- customer-driven quality;

- top management leadership and commitment;

- continuous improvement;

- fast response;

- actions based on facts;

- employee participation; and

- a TQM culture (Crosby, 1979; Deming, 1986; Juran and Gryna, 1995). 


\section{Customer-driven quality}

TQM has a customer-first orientation. The customer, not internal activities and constraints, comes first. Customer satisfaction is seen as the organization's highest priority and the organization believes it will only be successful if customers are satisfied. The TQM organization is sensitive to customer requirements and responds rapidly to them. In the TQM context, "being sensitive to customer requirements" goes beyond defect and error reduction and merely meeting specifications or reducing customer complaints. The concept of requirements is expanded to take in not only product and service attributes that meet basic requirements, but also those that enhance and differentiate them for competitive advantage. Each part of the organization is involved in total quality, operating as a customer to some functions and as a supplier to others.

\section{TQM leadership from top management}

TQM is a way of life for an organization. It has to be introduced and led by top management. This is a key point. Attempts to implement TQM often fail because top management does not lead and get committed instead it delegates and pays lip service. Commitment and personal involvement is required from top management in creating and deploying clear quality values and goals consistent with the objectives of the company, and in creating and deploying well-defined systems, methods and performance measures for achieving those goals. These systems and methods guide all quality activities and encourage participation by all employees. The development and use of performance indicators is linked, directly or indirectly, to customer requirements and satisfaction, and to management and employee remuneration.

\section{Continuous improvement}

Continuous improvement of all activities is at the heart of TQM. Once it is recognized that customer satisfaction can only be obtained by providing a high-quality product, continuous improvement of the quality of the product is seen as the only way to maintain a high level of customer satisfaction. As well as recognizing the link between product quality and customer satisfaction, TQM also recognizes that product quality is the result of process quality. As a result, there is a focus on continuous improvement of the organisation's processes. This will lead to an improvement in process quality.

\section{Fast response}

To achieve customer satisfaction, the organization has to respond rapidly to customer needs. This implies short product and service introduction cycles. These can be achieved with customer-driven and process-oriented product development because the resulting simplicity and efficiency greatly reduce the time involved. Simplicity is gained through concurrent product and process development. Efficiencies are realized from the elimination of non-value-adding effort such as re-design. The result is a dramatic improvement in the elapsed time from product concept to first shipment.

\section{Actions based on facts}

The statistical analysis of manufacturing facts is an important part of TQM. Facts and analysis provide the basis for planning, review and performance tracking, improvement of operations, and comparison of performance with competitors. The TQM approach is based on the use of objective data, and provides a rational 
rather than an emotional basis for decision-making. The statistical approach to process management in manufacturing recognizes that most problems are system-related, and are not caused by particular employees.

\section{Employee participation}

A successful TQM environment requires a committed and well-trained employee that participates fully in quality improvement activities. Such participation is reinforced by reward and recognition systems which

emphasize the achievement of quality objectives. Ongoing education and training of all employees supports the drive for quality. Employees are encouraged to take more responsibility, communicate more effectively, act creatively, and innovate. As people behave the way they are measured and remunerated, TQM links remuneration to customer satisfaction metrics.

\section{A TQM culture}

It is not easy to introduce TQM. An open, cooperative culture has to be created by management. Employees have to be made to feel that they are responsible for customer satisfaction. They are not going to feel this if they are excluded from the development of visions, strategies, and plans. It is important that they participate in these activities. They are unlikely to behave in a responsible way if they see management behaving irresponsibly - saying one thing and doing the opposite.

\section{Relationship between library science and TQM}

Quality, with regard to the products of industries, depends on raw materials, vendor components, different skills of performance of employees and production processes, and equipment that shows different degrees of performance. Similarly, quality with regard to library and information science or with respect to the processing of information services in the library depends on:

- the collection of documents and their technical processing by applying certain techniques and methods;

- the skills of employees;

- equipment and processing;

- the span of time of service to be rendered; and

- the attributes of services which are to be rendered.

From the above, it is clear that while quality in respect of industries fulfills the ultimate goal of user satisfaction, the same may be adopted in library and information centers.

Quality in library services is most effective in user-oriented services (Talukder and Ghosh, 2004). Talukder and Ghosh (2004) also made a comparison between TQM and library sciences in respect of different attributes as summarized in Table I. 


\begin{tabular}{|l|l|l|}
\hline Attribute & TQM & Library Sciences \\
\hline Definition & Customer oriented & User oriented \\
\hline Priorities & $\begin{array}{l}\text { First among equals of } \\
\text { service and cost }\end{array}$ & User and Service \\
\hline Decisions & Long Term & Long Term \\
\hline Emphasis & Prevention & $\begin{array}{l}\text { Prevention like } \\
\text { anticipation of demand }\end{array}$ \\
\hline Errors & System & System/techniques \\
\hline Responsibility & Everyone & Library personnel \\
\hline Problem Solving & Teams & Professionals' teams \\
\hline Procurement & $\begin{array}{l}\text { Life cycle costs, } \\
\text { partnership }\end{array}$ & $\begin{array}{l}\text { User centric ( cost is } \\
\text { implicit) }\end{array}$ \\
\hline Manager's Role & $\begin{array}{l}\text { Delegate, Coach, } \\
\text { Facilitate }\end{array}$ & $\begin{array}{l}\text { Delegate Assistance } \\
\text { Fande and mentor }\end{array}$ \\
\hline
\end{tabular}

Table I: Relationship between Library Science and TQM

The concept of total quality management (TQM) is now a management technique used in most disciplines and libraries and information centers are no exception. Its application in service sectors like library and information services (LISs) started in the late 1980s and is an American response aiming at customer satisfaction by way of meeting the requirements and expectations of customers. This concept has become more relevant in the current technological era, especially due to the emergence of application of information technology in libraries and changes in information consciousness among users (Raina, 1995).

\section{TQM implementation in libraries}

In this section, we will review the implementation of TQM in libraries that have adopted this model. As noted, use of TQM in the library sector started in the late 1980s, though early studies show that the TQM approach was not successful in some libraries. In fact, since TQM was originally developed for industrial production rather than service organizations, some of the highly statistical procedures applicable in industry are not appropriate for libraries. A study in British industry showed that although nearly two-thirds had introduced quality programs, only 8 percent of firms rated them as totally successful; this leaves a larger number that were claimed to be moderately successful, but the results are still far from impressive. Perhaps too much was expected too soon; perhaps some of the numerous critical success factors were neglected (Porter and Parker, 1993).

Stella Pilling (1997) stressed that several major features of total quality management (TQM) are highly relevant for libraries, such as:

- $\quad$ the emphasis on customers;

- $\quad$ the delegation of work;

- $\quad$ the involvement of staff at all levels;

- $\quad$ process rather than function; and

- $\quad$ the need for continuous improvement. 
The British Library Document Supply Centre (BLDSC) embarked on its TQM program in 1992, as greater awareness of customer needs, budget constraints and increasing competition in the document supply business made it vital that the Centre should re-examine its processes to ensure that it continued to meet customers' requirements for quality and service (Pilling, 1997).

There is also the important principle that quality must be appropriate to need, not necessarily intrinsically "high". What TQM does is to bring these very desirable features together and provide a set of techniques for achieving improvement -techniques that have to be painstakingly learned. Several libraries have claimed considerable success in the application of TQM, although time is needed if full success is to be achieved (Fitch et al., 1993).

A paper published in 1997 discusses the possible application of various TQM tools in cataloguing operations (Khurshid, 1997). The paper focused on the methods libraries have adopted to identify user needs and to improve services to meet user needs. The results showed that many of these methods are either based on the TQM philosophy or can be adapted to it.

In 1998, a study examined TQM implementation in three community college libraries and/or learning resources centers in the USA (Byrd, 1998). The results showed that the leadership role is significant in promoting among staff the goal of never-ending improvement and in maintaining the momentum of the quality effort. The results also indicated that TQM does have the power to transform libraries in the following broad categories:

- $\quad$ management;

- cross-training;

- $\quad$ staff development; and

- technology.

A comparison of the remarks of three staff about what advice they would give to a community college library thinking about implementing quality reveals that they would inform fellow colleagues of four things:

(1) TQM takes time and work;

(2) the institution's top management employees must support TQM;

(3) top managers at the institutional level must relinquish control in favor of participatory management for TQM to work; and

(4) the TQM effort must involve everyone in the institution.

A paper published in 2000 presents the implementation of TQM in the central library of the National Technical University of Athens in Greece (Adamantidou and Kouri, 2000). The paper concludes that there is no perfect example of the implementation of improvement processing of quality, just as there is no perfect model of reorganization. The proper approach that will be adopted will be in connection with the internal philosophy, culture and the external environment of the library in which it will be implemented.

A paper published in 2001 stresses the importance of marketing and total quality management in libraries in Ghana as the numbers of users in all types of libraries are increasing and users demand quality service (Alemna, 
2001). The paper concludes that libraries in Ghana are indeed in a time of great challenges, and if they are to be prevented from becoming the dinosaurs of the future, then total quality managementsand marketing strategies must be adopted to prevent them from imminent collapse.

A paper published in Reference Services Review presented TQM implementation in reference services and its future (Whitlatch, 2003). It addressed that the ability to design reference services that users will continue to value in libraries of the future is limited by current professional reference practices. These limits are related to the failure to incorporate total quality management (TQM) principles into the design and practice of present-day reference services. The following TQM principles were utilized to discuss the contrasts between TQM principles and current reference practices:

- $\quad$ focus on the customer;

- $\quad$ quality work the first time;

- $\quad$ strategic holistic approach to improvement;

- $\quad$ continuous improvement as a way of life; and

- $\quad$ mutual respect and teamwork.

Finally, the roles that library organizations must fulfill to change the current professional culture are described. Hainan University Library implemented TQM in July 2004 and passed the authentication of ISO 9000:2000 in 2005. The TQM implementation brought many changes in this library and brought it from being an isolated island into the international arena (Zhan and Zhang, 2006).

A paper published in Library Management addressed the process of implementing TQM in libraries, stating that it involves a conceptual change in library professionals and a cultural transformation in the organizational operations (Wang, 2006).

Teamwork is important for the successful implementation of TQM. Every step of the process depends on the constant support of top management. Their role determines how far the implementation can go. Therefore, once a decision is made to apply TQM, strong leadership is required. TQM provides a model and a benchmark as guidelines in making new strategies in libraries facing today's great changes. It is arguable whether it is feasible to apply the principles without reservation, but it is reasonable to adopt the techniques with adaptations suitable to the library environment.

In India, the library of the Indian Institute of Management, Lucknow (IIML) has been conducting innovative continuing professional development programs for professionals engaged in the library and information sector for many years. More than 30 such programs are employed in the context of library and information systems and services, in areas such as:

- $\quad$ quality management;

- $\quad$ marketing;

- $\quad$ information technology applications;

- $\quad$ human relations; and

- communication. 
Feedback from the participants has continually been revealing that the programs were very well received, and at times had even surpassed expectations. As a result, significant positive developments have also been seen to have taken place in many of the participants' library and information systems as far as their collection development, collection organization, service design and delivery activities are concerned (Raina, 2005).

Institutionalizing TQM in a library requires a quality culture among the library team that prompts customer delight through continuous improvement involving participatory and creative problem-solving approaches and a team ethos. Another study among Indian research libraries (Sherikar and Jange, 2006) showed that none of respondents were fully satisfied with the work culture in their library. However, the majority of professional staff were highly satisfied with the librarian's leadership quality, creating and maintaining cordial relationships amongst library professionals. A key observation was that in services there was a direct interaction between a customer and the library staff and fulfilling their requirements through the service delivery process is both challenge and an opportunity. A university library adopting total quality management in its activities and services needs to emphasize the importance of quality management to services.

\section{Barrier factors for TQM implementation in LIS}

The history of TQM in manufacturing shows that there are some barriers in TQM implementation. Some of these barriers are common in service sectors including libraries. TQM implementation failure has been attributed to two main barriers. The first is organizational context, such as a rigid organizational culture that is inflexible and a highly bureaucratic organizational structure and authoritarian management style. That is, the failures of TQM implementations are due not to external factors but to the failure of management to establish a proper system for its implementation (Shin et al., 1998; Wilkinson et al., 1995). This perspective argues that often managers are not fully aware, or perhaps ignore, what it takes to implement TQM successfully and achieve high performance.

The second is the cultural barrier, because TQM implementation involves a paradigm shift in management values and attitudes and it should fit the national culture of the firm if it is to be implemented successfully (Sohal et al., 1998; Tata et al., 1999). Research on the culture barrier argues that management values differ significantly across national cultures, that management is culture-specific and that managerial practices, such as TQM, must be tailored to fit the local culture (Bartlett and Ghoshal, 1992; Trompenaars, 1994).

TQM is about transforming an organization's culture, yet with the expectation of establishing a quality infrastructure and eliminating middle management positions through attrition. It is difficult to make a change in organizational structures as TQM requires institutions to restructure. Resistance to change and people's attitudes are primary hindrances to implementing TQM in libraries. The other barriers are the problems of finding the money and time for training while maintaining current services in the library.

Miller and Stearns (1994) listed the following barriers to the implementation of TQM in libraries:

- the view that this is just another management fad of the day;

- management's fear of the loss control;

- employee reluctance to recommend changes because of fear of management; 
- the business and industrial background of TQM might not lend itself to the non-profit sector, including libraries;

- TQM requires a long-term investment of time over several years as processes are analyzed and an organization's culture is changed - this can cause resistance; and

- other difficulties in these days of increasing financial and other pressures

Other research has focused on individuals within an organization. For example, Reger et al. (1994) suggest that each person's response to an idea involves the cognitive process of interpretation, attribution and inference. This means that managers who propose the idea for quality improvement are convinced that it works and assume that employees will think so too (Reger et al., 1994). Candido and Morris (2000) describe TQM failure as the expression of differing desires, wants, needs and feelings at individual levels within the organization. However, the underlying causes of failure in the implementation of TQM may go beyond individual beliefs, expectations, cognitive processes of interpretation, perceptions, feelings, and desires to more deeply rooted unconscious archetypical projections on the part of each individual in the organization.

\section{Conclusion}

This paper has discussed the implementation of total quality management and its application to libraries. TQM demands time and persistence. To succeed in an organization there must be support at the very top and commitment at all levels. It is necessary that all groups of people in an organization are included in the process. TQM implementation requires patience and tolerance as it is a time-consuming process and, of course, it is not easy to change an organization. Therefore, implementation of TQM is not a guarantee of the highest quality but it is a step in the right direction. TQM implements a philosophy of strong leadership participation, increased communication among departments, and the education of all employees. TQM is proven to be profitable when implemented in a successful way, but there are also problems with the implementation. In the other word, there is a need for an increased focus on the area of organizational change related to TQM.

Resistance to change and people's attitudes are the primary hindrances to implementing TQM in libraries. The other barriers are the problems of finding the money and time for training while maintaining current services in the library. TQM is about transforming an organization's culture, yet with the expectation of establishing a quality infrastructure and eliminating middle management positions through attrition. It is difficult to make a change in organizational structures, yet TQM requires institutions to restructure.

Successful TQM implementation requires a thorough understanding of critical success factors, barriers to achieving these factors, and managerial tools and techniques to overcome these barriers. Research in developed countries listed top management commitment to TQM, training for TQM throughout the organization, customer focus and continuous improvement, and a focus on employee involvement and empowerment as the key determinants of successful TQM implementation. 


\section{References}

Adamantidou, E. and Kouri, R. (2000), "Efforts of implementing TQM in the Central Library of the National Technical University of Athens", Proceedings of the 9th Panhellenic Conference of Academic libraries, Athens, pp. 221-6.

Alemna, A.A. (2001), “The need for marketing and total quality management strategies in libraries in Ghana”, INSPEL, Vol. 35 No. 4, pp. 265-9.

Bartlett, C.A. and Ghoshal, S. (1992), Transnational Management: Text, Cases and Readings in Cross-border Management, Irwin, Homewood, IL.

Buzzell, R.D. and Gale, T. (1987), The PIMS Principle, The Free Press, New York, NY.

Byrd, T.S. (1998), “Total quality management implementation in three community college libraries and/or learning resources centers”, PhD thesis, University of Virginia, Charlottesville, VA.

Candido, C.J.F. and Morris, D.S. (2000), “Charting service quality gaps”, Total Quality Management, Vol. 11 Nos 4-6, pp. 463-72.

Churchill, G.A. Jr and Paul, P.J. (1994), Marketing: Creating Value for Customer, Irwin, New York, NY.

Crosby, P.B. (1979), Quality Is Free, McGraw-Hill, New York, NY.

Deming, W.E. (1986), Out of the Crisis, MIT Press, Cambridge, MA.

Fitch, D.K., Thomason, J. and Wells, E.C. (1993), “Turning the library upside down: reorganization using total quality management principles”, Journal of Academic Librarianship, Vol. 19 No. 5, pp. 294-9.

Garvin, D.A. (1988), Managing Quality, The Free Press, New York, NY.

Handy, C. (1994), The Empty Raincoat: Making Sense of the Future, Hutchinson, London.

Juran, J.M. and Gryna, F.M. Jr (1995), Quality Planning and Analysis., McGraw-Hill, New York, NY.

Khurshid, Z. (1997), “The application of TQM in cataloguing”, Library Management, Vol. 18 No. 6, pp. 274-9.

Miller, R.G. and Stearns, B. (1994), “Quality management for today’s academic library”, College \& Research Libraries News, Vol. 55 No. 7, pp. 406-22.

Pilling, S. (1997), "Putting the customer first: total quality and customer service at the British Library Document Supply Centre", Asian Libraries, Vol. 6 Nos 1/2, p. 6.

Porter, L.J. and Parker, A.J. (1993), “Total quality management - the critical success factors”, Total Quality Management, Vol. 4 No. 3, pp. 13-22.

Price, M. and Chen, E. (1993), “TQM in a small high-technology company”, California Management Review, Vol. 35, pp. 96117.

Raina, R.L. (1995), “TQM in library and information services”, University News, Vol. 33 No. 24, pp. 4-6.

Raina, R.L. (2005), "Innovative continuing professional development programs for LIS professionals conducted by the Library at IIM Lucknow: an overview”, available at: www.ifla.org/IV/ifla71/papers/042e-La-Raina.pdf

Reger, R.K., Gustafson, L.T., Damarie, S.M. and Mullane, J.U. (1994), "Reframing the organisation: why implementing total quality is easier said than done”, Academy of Management Review, Vol. 19 No. 3, pp. 565-84.

Schein, L. (1991), Communicating Quality in the Service Sector, The Conference Board, New York, NY.

Sherikar, A. and Jange, S. (2006), “Towards quality culture in the digital environment: management and optimization of services in research libraries of India”, in Grove, A. (Ed.), Proceedings of the 69th Annual Meeting of the American Society for Information Science and Technology (ASIST), Austin, TX, p. 43. 
Shin, D., Kalinowski, J.G. and El-Enein, G.A. (1998), “Critical implementation issues in total quality management”, SAM Advanced Management Journal, Vol. 63, pp. 10-15.

Sohal, A.S., Samson, D. and Ramsay, L. (1998), "Requirement for successful implementation of total quality management”, International Journal of Technology Management, Vol. 16, pp. 505-19.

Talukder, T. and Ghosh, S. (2004), “Total quality management and its implication on library laws”, SRELS Journal of Information Management, Vol. 41 No. 3, pp. 255-66.

Tata, J., Prasad, S. and Thorn, R. (1999), “The influence of organizational structure on the effectiveness of TQM programs”, Journal of Managerial Issues, Vol. XI, pp. 440-53.

Torrington, D. and Hall, L. (1995), Personnel Management: HRM in Action, Prentice-Hall International, Hemel Hempstead.

Trompenaars, F. (1994), Riding the Waves of Culture, Irwin, New York, NY.

Wang, H. (2006), “From 'user’ to ‘customer’: TQM in academic libraries?”, Library Management, Vol. 27 No. 9, p. 606.

Whitlatch, J.B. (2003), “Reference futures: outsourcing, the web, or knowledge counseling?”, Reference Services Review, Vol. 31 No. 1, pp. 26-30.

Wilkinson, A., Redman, T. and Shape, E. (1995), “New patterns of quality management in the United Kingdom”, Quality Management Journal, Winter, pp. 7-49.

Zeithaml, V.A., Parasuraman, A. and Berry, L.L. (1990), Delivering Quality Service, The Free Press, New York, NY.

Zhan, C. and Zhang, H. (2006), "How does a dandelion seed from overseas root and thrive? The successful implementation of TQM in Hainan University Library”, Library Management, Vol. 27 Nos 6/7, p. 344. 